\title{
Risk Factors for Increased Urinary Cadmium Levels among a Rural Population Living Near a Dumpsite in the Deli Serdang District of Indonesia
}

\section{Yulia Khairina Ashar, Fajrin Nur Azizah, Haeranah Ahmad, Zakianis, and Ririn Arminsih Wulandari}

Departement of Environmental Health, Faculty of Public Health, Universitas Indonesia, Depok, Indonesia

\section{Abstract}

Cadmium (Cd) is a toxic mineral, which occurs naturally in the environment and as a result of agricultural and industrial activities. It is also a carcinogenic heavy metal. After exposure, $\mathrm{Cd}$ accumulates in the kidney and is excreted in urine. The urinary $\mathrm{Cd}$ level is considered a biomarker of long-term exposure to the mineral. The aim of this

Corresponding Author: Ririn Arminsih Wulandari uwaraw@yahoo.com

Received: 21 January 2018 Accepted: 8 April 2018

Published: 17 May 2018

Publishing services provided by Knowledge E

(c) Yulia Khairina Ashar et al. This article is distributed under the terms of the Commons Attribution License, which permits unrestricted use and redistribution provided that the original author and source are credited.

Selection and Peer-review under the responsibility of the 2nd International Meeting of Public Health 2016 Conference Committee.

\section{G OPEN ACCESS} study was to analyze the association between urinary Cd levels and sociodemographic characteristics of a rural population living close to Namo Bintang dumpsite. This study used a cross-sectional design and consisted of 99 participants, which were selected using the stratified random sampling method according to the distance from their homes to the dumpsite area. Urinary Cd levels were measured at baseline using a graphite furnace atomic absorption spectrophotometer and normalized by urinary creatinine. Demographic data and exposure to Cd-related risk factors were obtained through a direct interview using a questionnaire. The urinary $\mathrm{Cd}$ level of all the participants exceeded guidelines (>5 $\mathrm{\mu g} / \mathrm{g}$ creatinine) according to the biological exposure indices of The American Conference of Governmental Industrial Hygienists (ACGIH). The presence of a smoking habit was significantly associated with increased urinary $\mathrm{Cd}$ levels $(p=0.041)$. It can be concluded that the community living close to the dumpsite has been exposed to $\mathrm{Cd}$, which was related to urinary Cd levels.

Keywords: cadmium; urinary Cd; heavy metal; dumpsite

\section{INTRODUCTION}

In Indonesia, the disposal of waste in open dumps rather than in landfill sites remains the predominant method of waste management [6]. The disposal of waste in open dumps has the potential to pollute the environment, including contamination of groundwater by leachate [6]. This leachate may contain organic materials and heavy 
metals, such as cadmium (Cd) $[8,11]$. Cd in landfill is derived from plastics, batteries, and waste from industry (e.g., steel) [5].

$\mathrm{Cd}$ is released into the environment in wastewater. Diffusion pollution from fertilizers and local air pollution represents an additional source of Cd. Contamination of drinking water with Cd may occur as a result of impurities in zinc galvanized pipes, solders, and various types of metal fittings [17].

Food is the main source of daily exposure to $\mathrm{Cd}$. Cd contamination in a range of vegetables, including radishes, cress, dill, spinach, and eggplants, has been reported [18]. The daily oral intake of Cd was reported to be 10-35 $\mu$ [18]. Smoking is a significant additional source of Cd exposure [17]. Cd has highly toxic effects, even at low concentrations; furthermore, it cannot be degraded by living organisms and therefore accumulates in the environment (ATSDR 2008; $[15,18]$ ). Exposure to $C d$ in the environment can increase the incidence of various types of cancers, such as lung, prostate, kidney, endometrial, breast, and stomach [10]. Exposure to Cd also increases the risk of cardiovascular disease [12].

Urinary Cd levels have been shown to accurately reflect the amount of $\mathrm{Cd}$ in the body, both past and present exposure. Cd levels in blood reflect recent exposure. The aim of this study was to analyze the association between urinary Cd levels and sociodemographic characteristics of a rural population living close to Namo Bintang dumpsite.

\section{METHODS}

This was a cross-sectional study of a rural community living close to Namo Bintang dumpsite in the Deli Serdang District, North Sumatra Province, Indonesia. The study included all females and males aged $\geq 18$ years who had lived close to the study site for at least 7 years and were willing to provide urine samples and to be interviewed.

Spot urine samples were collected from the participants in the morning. The samples were analyzed using a Z-5700 polarized Zeeman graphite furnace atomic absorption spectrophotometer. The $\mathrm{Cd}$ concentration in the samples was determined using standard methods. 


\subsection{Statistical Analysis}

Kolmogorov-Smirnov and Shapiro-Wilk tests were conducted and indicated that the data were not normally distributed. Spearman's correlation test was performed to evaluate the association between age and urinary $\mathrm{Cd}$ levels.

\section{RESULTS}

As shown in Table 1, the urinary Cd level of the participants normalized to creatinine ranged from 6.1 to $206.1 \mu \mathrm{g} / \mathrm{g}$ creatinine, with an average of $35.15 \mu / g(S D \pm 32.65$ $\mu \mathrm{g} / \mathrm{g}$ creatinine).

TABLE 1: Descriptive Statistics of Urinary Cd Levels.

\begin{tabular}{|l|c|c|c|c|c|c|}
\hline Variable & Mean & Median & SD & Min-Max & $95 \% \mathrm{Cl}$ \\
\hline Urinary Cd $(\mu / g$ creatinine $)$ & 35.15 & 22.37 & 32.65 & $6.1-206.1$ & $28.6-41.7$ \\
\hline
\end{tabular}

Table 2 shows the demographic characteristics of the participants $(n=99)$. The ages of the participants ranged from 19 to 75 years. The average age was 42.32 years (SD \pm 13.07 years). There were 26 men and 73 women, of whom $10.1 \%$ had occupational exposure to $\mathrm{Cd}$. In the study, $40.4 \%$ of the participants were smokers, and $59.6 \%$ were nonsmokers. Most of the participants were not obese.

TABLE 2: Demographic Characteristics of the Participants.

\begin{tabular}{l|c}
\hline $\begin{array}{l}\text { Variable } \\
\text { Age }\end{array}$ & $42.32 \pm 13.07$ \\
\hline Mean \pm SD & $19-75$ \\
\hline Min-Max & Frequency (\%) \\
Variable & \\
Sex & $26(26.3)$ \\
\hline Men & $73(73.7)$ \\
\hline Women & \\
\hline Occupational exposure to Cd & $89(89.9)$ \\
\hline Not exposed & $10(10.1)$ \\
\hline Exposed & \\
\hline Smoking habit & $59(59.6)$ \\
No & $40(40.4)$ \\
\hline Yes & \\
\hline BMI & $29(29.3)$ \\
\hline Obese & $70(70.7)$ \\
\hline Non Obese
\end{tabular}




\subsection{Age and Urinary Cd levels}

As shown by the results of Spearman's correlation test, there was a weak but significant correlation between age and urinary Cd levels $(r=0.158, p=0.117)$ (Table 3).

TABLE 3: Correlation between Age and Urinary Cd Levels.

\begin{tabular}{l|c|c|c}
\hline Variable & Mean (SD) & Correlation Coefficient & p value \\
\hline Age & $42.32(13.07)$ & $-0.158^{*}$ & 0.117 \\
\hline
\end{tabular}

\subsection{Demographic Characteristics of the Participants and Urinary Cd Levels}

There was no significant association between the urinary Cd levels and sex, occupation, and body mass index (BMI) of the participants (Table 4 ). However, there was significant association between urinary $C d$ levels and smoking habits $(p=0.041)$.

TABLE 4: Demographic Characteristics of the Participants.

\begin{tabular}{|c|c|c|c|c|}
\hline Variable & $n$ & Mean & SD & $p$ value \\
\hline Sex & & & & 0.135 \\
\hline Men & 26 & 25.37 & 16.92 & \\
\hline Women & 73 & 38.63 & 36.13 & \\
\hline Occupational exposure to $\mathrm{Cd}$ & & & & 0.134 \\
\hline Not exposed & 89 & 32.41 & 27.46 & \\
\hline Exposed & 10 & 59.50 & 59.19 & \\
\hline Smoking habit & & & & 0.041 \\
\hline No & 59 & 30.04 & 24.27 & \\
\hline Yes & 40 & 42.68 & 41.30 & \\
\hline BMI & & & & 0.489 \\
\hline Obese & 29 & 44.45 & 44.85 & \\
\hline Not obese & 70 & 31.29 & 25.43 & \\
\hline
\end{tabular}

\section{DISCUSSION}

\subsection{Age and Urinary Cd Levels}

According to a previous report, when exposure to $\mathrm{Cd}$ remained constant, the content of $\mathrm{Cd}$ in the body increased with aging until age 50-60 years, in addition to renal accumulation of Cd (ATSDR, 2008). In the present study, age was not significantly associated with urinary $C d$ levels $(p=0.117)$. This finding is consistent with that 
reported in an earlier study, which also found no significant association between age and urinary Cd levels ( $p>0.05)$ [13].

\subsection{Sex and Urinary Cd Levels}

In contrast to most environmental pollutants, where the burden is higher in men than in women, women have a higher body burden of Cd [16]. Vahter et al. (2007) reported higher concentrations of $\mathrm{Cd}$ in blood, urine, and kidney cortex of women as compared to men. The main reason for the higher $\mathrm{Cd}$ burden in women is increased intestinal absorption of dietary Cd when iron stores of the body are low. In the present study, there was no significant association between sex and urinary Cd levels. This finding can be explained by the study population, which did not include menstruating or pregnant women or those with malignancies and kidney diseases, all of which can increase $\mathrm{Cd}$ levels in the body.

\subsection{Occupation and Urinary Cd Levels}

The results of the present study differed from those reported in a previous study in Thailand by Sirivarasai (2002), who found that the blood concentration of $\mathrm{Cd}$ in the general population was lower than that of individuals with occupational exposure to $\mathrm{Cd}$. According to a previous report, in workers with occupational exposure to $\mathrm{Cd}$, urinary $\mathrm{Cd}$ excretion increased in accordance with the accumulation of $\mathrm{Cd}$ in the body [2]. However, in the absence of kidney damage, the amount of $\mathrm{Cd}$ that was excreted accounted for only a small part of total Cd [2].

\subsection{Smoking Habits and Urinary Cd Levels}

In the present study, the results of the Mann-Whitney test pointed to a significant association between smoking habits and increased urinary $C d$ levels $(p=0.041)$. This significant association could be explained by the long half-life of $\mathrm{Cd}$. As reported in a previous study, the concentration of $C d$ in urine increased in the presence of smoking habits because of the long half-life (10-30 years) of Cd. According to one study, the urinary Cd concentration in smokers was two to four times higher than that in nonsmokers [7]. Another study reported that when classified by the number of cigarettes smoked per day, the urinary Cd level in current smokers increased in accordance with the number of cigarettes consumed (about $0.09 \mu \mathrm{g} /$ cigarettes/day), leveling off after 
15 or more cigarettes [9]. However, a study of the amount of Cd absorbed in cigarette smokers and urinary $\mathrm{Cd}$ levels suggested that almost all the $\mathrm{Cd}$ absorbed was excreted in urine.

\subsection{BMI and Urinary Cd Levels}

The present study found no significant association between BMI and increased urinary Cd levels. This finding is in accordance with that of a previous study [14]. However, another study found a significant association between the BMI and urinary Cd levels [4].

\section{CONCLUSIONS}

This study found no association between urinary Cd levels and age, sex, occupation, and BMI. There was a significant association between smoking habits and urinary $\mathrm{Cd}$ levels. Thus, Cd exposure may be important in the development of tobacco-related lung disease.

\section{ACKNOWLEDGEMENTS}

We thank to our research sponsor the Directorate of Research and Community Service of the University of Indonesia for assistance provided under the PITTA scheme (International Indexed Publication of Student Research Paper Grant).

\section{References}

[1] ACGIH. 2012. Appendix B: Biological exposure guidelines (ACGIH BEI and OSHA expanded standards only). Retrieved from https://www.osha.gov/dts/osta/otm/ otm_ii/pdfs/otmii_chpt2_appb.pdf. [Accessed February 12, 2016].

[2] Agency for Toxic Substances and Disease Registry (ATSDR). 2012. Toxicological profile for cadmium.

[3] Agency for Toxic Substances and Disease Registry (ATSDR). 2007. Toxicological profile for benzene. Retrieved from http://www.atsdr.cdc.gov/toxprofiles/ tp3-c8.pdf.

[4] Akesson, A., Bettina J., and Wolk, A. 2008. Prospective cohort study endometrial cancer incidence: A population-based long-term dietary cadmium intake and 
postmenopausal. Cancer Res 68: 6435-6441.

[5] Aucott, M. 2006. The fate of heavy metals in landfills: a review. Industrial ecology, pollution and the NY-NJ Harbour. New York: New York Academy of Sciences.

[6] Erwin. 2012. TPA Sampah, Ancaman Kesehatan Lingkungan dan Pangan. Retrieved from http://www.scribd.com/doc/116971751/TPA-Sampah-for-EXPO. [Accessed June, 7 2016].

[7] Galazyn-Sidorczuk, M., Brzoska, M. M., and Moniuszko-Jakoniuk, J. 2008. Estimation of Polish cigarettes contamination with cadmium and lead and exposure to these metals via smoking. Environ Monit Assess 137: 481-493.

[8] Himmah, Aminudi, dan Milala. 2009. Potensi Limbah Air Lindi oleh Pseudomonas fluoresens sebagai Prebiotik Tanaman. Institut Pertanian Bogor. Bogor. Retrieved from http://www.iarc.fr/en/publications/list/monographs. [Accessed June 11, 2016].

[9] Ikeda, M., Moriguchi, J., Ezaki, T., Fukui, Y., Ukai, H., Okamoto, S., Shimbo, S., and Sakurai, H. 2005. Smoking-induced increase in urinary cadmium levels among Japanese women. Int Arch Occup Environ Health 78: 533-540.

[10] Johri, N., Jacquillet, G., and Unwin, R. 2010. Heavy metal poisoning: The effects of cadmium on the kidney. Biometals 23: 783-792.

[11] Maramis, Kristijanto, dan Notosoedarmo. 2006. Sebaran Logam Berat dan Hubungannya dengan Faktor Fisiko-Kimiawi di Sungai Kreo, Dekat Buangan Air Lindi TPA Jatibarang. Akta Kimindo 1(2): 93-97.

[12] Peters, J. L., Perlstein, T. S., Perry, M. J., McNeely, E., and Weuve, J. 2010. Cadmium exposure in association with history of stroke and heart failure. Environ Res 110: 199-206.

[13] Sirivarasai, J., Kaojaren, S., Wananukul, W., and Srisomerang, P. 2002. Nonoccupational determinants of cadmium and lead in blood and urine among a general population in Thailand. Division of Clinical Pharmacology and Toxicology, Department of Medicine, Mahidol University.

[14] Teeyakasema, W., Nishijo, M., Honda, R., Satarug, S., Swaddiwudhipong, W., and Ruangyuttikarn, W. 2007. Monitoring of cadmium toxicity in a Thai population with high-level environmental exposure.

[15] UNEP (2008). Draft final review of scientific information on cadmium. United Nations Environment Programme, Chemicals Branch. (http://www.chem.unep.ch/Pb_and $\mathrm{Cd} / \mathrm{SR} /$ Draft_final_reviews/Cd_Review/Final_UNEP_Cadmium_review_Nov_ 2008.pdf). 
[16] Vahter, M, Akesson, A, Liden, C., Ceccatelli, S., and Berglund M. 2007. Gender differences in the disposition and toxicity of metals. Environ Res 104: 85-95.

[17] World Health Organization (WHO). 2003. Brominated acetic acid in drinking water. In Background document for preparation of WHO guidelines for drinking water quality. Geneva: WHO.

[18] World Health Organization(WHO). 2011. Cadmium in drinking water. In Background document for preparation of WHO guidelines for drinking water quality. Geneva: WHO. 